\title{
Antiproliferative Effect of Alpha Amyrin on Hep2 Cells by Inducing Cytotoxicity and Oxidant Antioxidant Status Modifications
}

\author{
Sankaran Mirunalini", Stainsloss Isabella and Veluchamy Vaithiyanathan \\ Department of Biochemistry and Biotechnology, Faculty of Science, Annamalai University, \\ Annamalai Nagar - 608 002, Tamil Nadu, India; mirunasankar@gmail.com
}

\begin{abstract}
Alpha amyrin, a plant bioactive triterpenoids, present in higher plants and particularly in Pergularia daemia. The compound alpha amyrin is a potent antioxidant, anti-inflammatory and antinociceptive, antipruritic, gastro protective and hepatoprotective agent. The anticancer effect of alpha amyrin has not been examined in human laryngeal cancer model. So this study evaluated its potential on Hep2 cells and anti-oxidant modifications. The current investigations explored the alpha amyrin possessed excellent manner $(10,20,40,80,160$ and 320$) \mu \mathrm{mol} / \mathrm{ml}$ and the IC $_{50}$ value was found to be $69.32 \mu \mathrm{mol} / \mathrm{ml}$. The TBARS level increased and antioxidant levels decreased in alpha amyrin treated Hep2 cells as compare to untreated cancer Hep2 cells. On the basis of our result alpha amyrin possess excellent antiproliferative ability on Hep2 cells by inducing cytotoxicity as well as oxidant antioxidant alterations. Therefore, alpha amyrin has therapeutic potential on various types of cancer.
\end{abstract}

Keywords: Alpha Amyrin, Anti-Oxidant, Laryngeal Cancer, Pergularia Daemia, Triterpenoids

\section{Introduction}

The most dependable predisposing epidemiologic factor related with laryngeal cancer is cigarette smoking. The common therapeutic modalities for laryngeal cancer comprise radiotherapy, chemotherapy and surgery through the goal to remove cancer. Several, natural products have been used in the place of anticancer drug. There is a resurgence of interest in plant derivative compounds for the mitigation of various ailments and a popular confidence is that naturally occurring products have smaller side effects.

Medicinal plants act as antioxidants due to their phenolic content. These compounds can also plays a role as pro oxidants at the desired dose range. One such phytochemical namely alpha-amyrin a pentacyclic triterpenoids compound which is isolated from higher plants such as $P$. heptaphyllum and $P$. daemia. have anticancer, analgesic and anti-inflammatory properties. As the anti-proliferative effect of alpha-amyrin is still un explored in this preclinical study, an effort had been made to investigate the ability of alpha-amyrin on cancer cell line. Hence, the aim is to determine the cytotoxic effect of alpha-amyrin by MTT assay on Hep2 cell line and analyse the modulatory effect of alpha-amyrin on lipid peroxidation markers (TBARS) and antioxidants (SOD, CAT, GPx, GSH) on human laryngeal cancer cell line (Hep2).

${ }^{*}$ Author for correspondence 


\section{Materials and Methods}

\subsection{Cell Line}

Hep-2 cell line was acquired from National Centre for Cell Science, Pune and maintained in Dulbecco's Minimum Essential Medium (DMEM) and were kept at $37^{\circ} \mathrm{C}$ in a humidified atmosphere of $5 \% \mathrm{CO}_{2}$ incubator.

\subsection{MTT Assay and Toxicity}

The cells were plated in 96 well, flat bottom tissue culture plates at a density of almost $1.2 \times 10^{4}$ cells/well and allowed to attach overnight at $37^{\circ} \mathrm{C}$. The medium was then removed and the cells were incubated with different concentrations of alpha amyrin $(10,20,40$, 80,160 and $320 \mu \mathrm{mol}$ ) for 24 hours. After the incubation, medium was discarded and $100 \mu \mathrm{l}$ of DMSO was added. Then, the absorbance was read at $570 \mathrm{~nm}$ in a micro titre plate reader.

$$
\text { So, } \% \text { Cytotoxicity }=\frac{\text { Test optical density }}{\text { Control optical density }} \times 100
$$

\subsection{Biochemical Estimations}

The concentration of TBARS in Hep2 cells were estimated by the method Niehaus and Samuelson et $\mathrm{al}^{1}$.The action of Superoxide Dismutase (SOD) was determined by the method of Kakkar et al., ${ }^{2}$ Catalase (CAT) activity was determined by the method of Sinha ${ }^{3}$ Determination of glutathione peroxidase (GPX) action was done by Rotruck et al. [4] Reduced glutathione (GSH) level was projected by the method of Ellman ${ }^{5}$.

\section{Results and Discussion}

\subsection{Cytotoxicity Assay (MTT)}

Figure 1 shows the cytotoxicity effect of alpha amyrin on human laryngeal cancer cell (Hep2). Alpha- amyrin inhibited the proliferation of Hep-2 cell lines with the IC50 value approximately $69.32 \mu \mathrm{mol} / \mathrm{ml}$. From this study, Alpha-amyrin possesses the higher inhibitory action on Hep-2 cell lines. The plot area of inhibition is shown in Figure 2. Among the six doses $(10,20,40$,
$80,160$ and $320 \mu \mathrm{mol})$ used for this study, we choose 40 , $80,160 \mu \mathrm{mol} / \mathrm{ml}$ as effective dose and the doses were used for future biochemical studies.

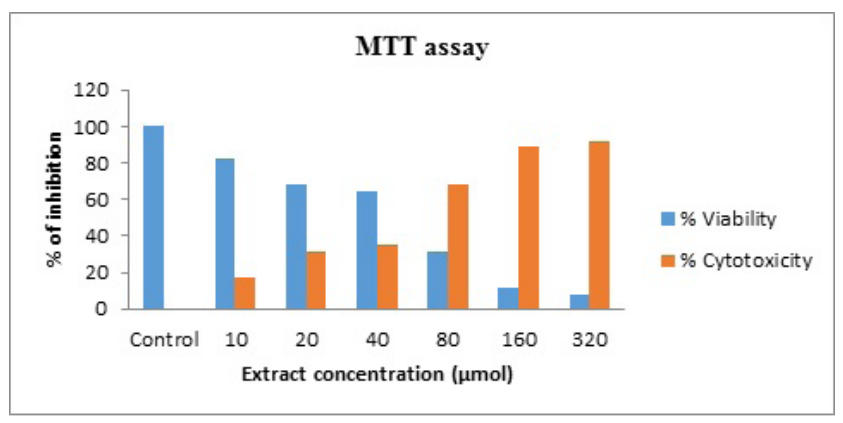

Figure 1. Cytotoxic effect of alpha-amyrin on human laryngeal cancer cells (Hep2).

The effect of alpha-amyrin on cell viability was determined by MTT assay. Hep2 cells were incubated with different concentrations of alpha amyrin (0-320 $\mu \mathrm{mol} / \mathrm{ml}$ ) for $24 \mathrm{~h}$.

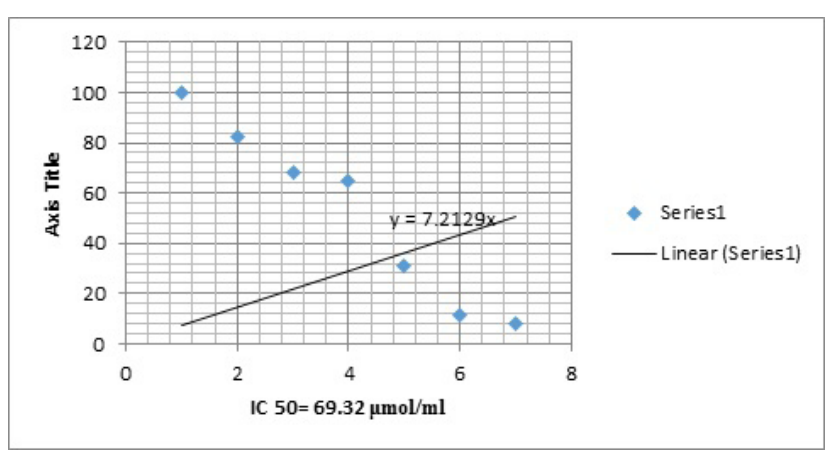

Figure 2. $\mathrm{IC}_{50}$ value of alpha-amyrin on human laryngeal cancer cells (Hep2).

\subsection{Changes in Level of Lipid Peroxidation in Hep2 Cancer Cell Line}

In this study, the role of alpha amyrin on oxidative damage in Hep2 cell line was investigated. Lipid peroxidation is used as an end point to study the action of pro-oxidant as well as to investigate the effect of antioxidants. 
From the results, alpha amyrin treatment increased the levels of lipid peroxidation in Hep2 cells (Figure 3).

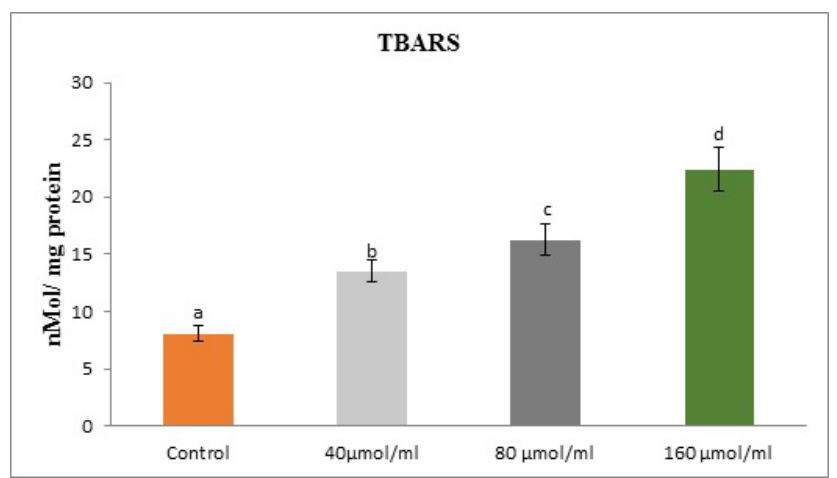

The values are given as mean \pm standard deviation of six experiments in each group (DMRT). Bars not sharing the common superscripts differ significantly at $p<0.05$.

Figure 3. TBARS levels in alpha-amyrin treated Hep2 cells.

\subsection{Changes in the Levels of Enzymatic Antioxidants}

In normal healthy cells, enzymatic and non-enzymatic antioxidants serve to stabilize the intracellular production of ROS, thereby postponing or preventing the destructive oxidation of molecular components.

In this study, the effect of on SOD, CAT, GPx and GSH activities in Alpha-amyrin treated Hep2 cancer cells were examined. Activities of enzymatic antioxidants such as SOD, CAT, GPx and GSH were showed in Figure (4-7). Alpha-amyrin (40, 80, $160 \mu \mathrm{mol} / \mathrm{ml})$ treatment significantly reduced antioxidant activities. Alphaamyrin at $160 \mu \mathrm{mol} / \mathrm{ml}$ concentration had good impact in decreasing the enzyme activity.

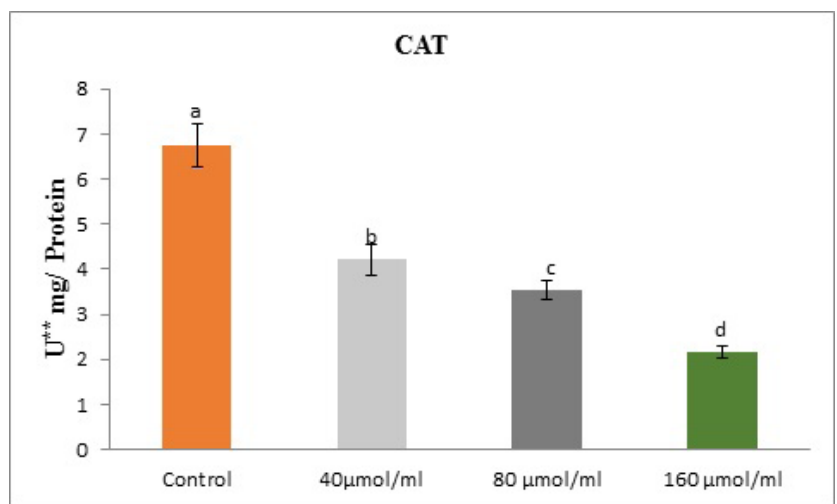

${ }^{*}$ Enzyme concentration required for $50 \%$ inhibition of nitro blue tetrazolium reduction in 1 minute.

Figure 4. Status of Super Oxide Dismutase (SOD) in alpha-amyrin treated Hep2 cells.

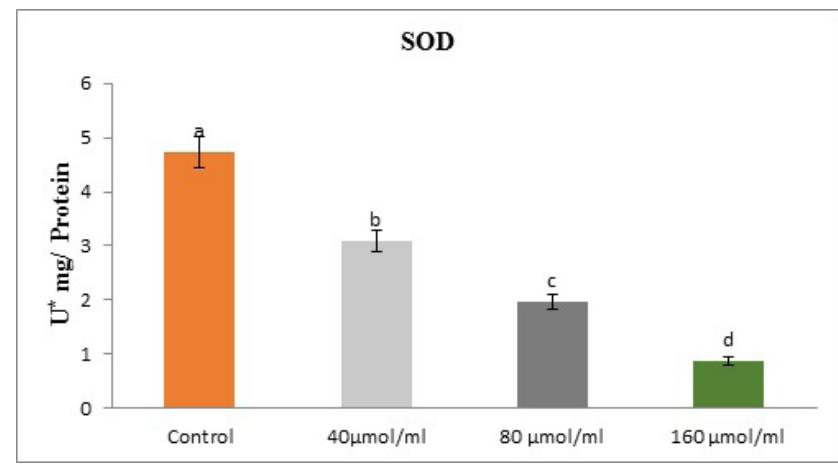

${ }^{*} \mu \mathrm{mol}$ of hydrogen peroxide consumed per minute.

Figure 5. Status of Catalase (CAT) in alpha-amyrin treated Hep2 cells.

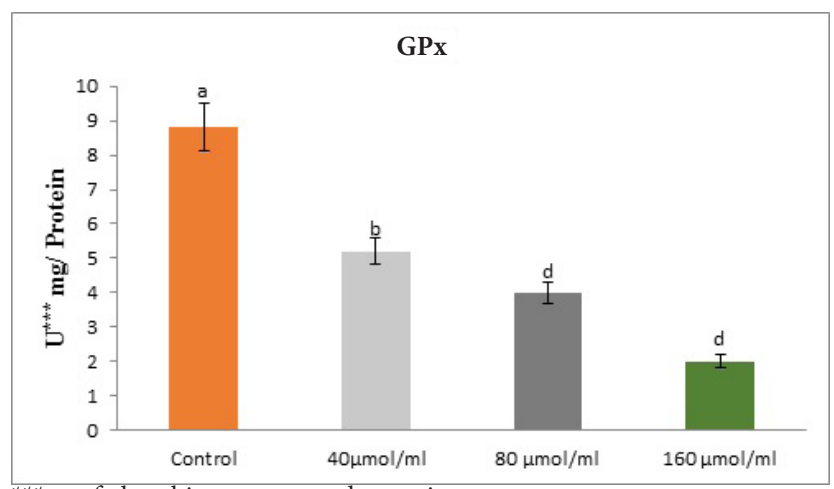

${ }^{\star * *} \mu \mathrm{g}$ of glutathione consumed per minute.

Figure 6. Status of Glutathione Peroxidase (GPx) in alpha-amyrin treated Hep2 cells.

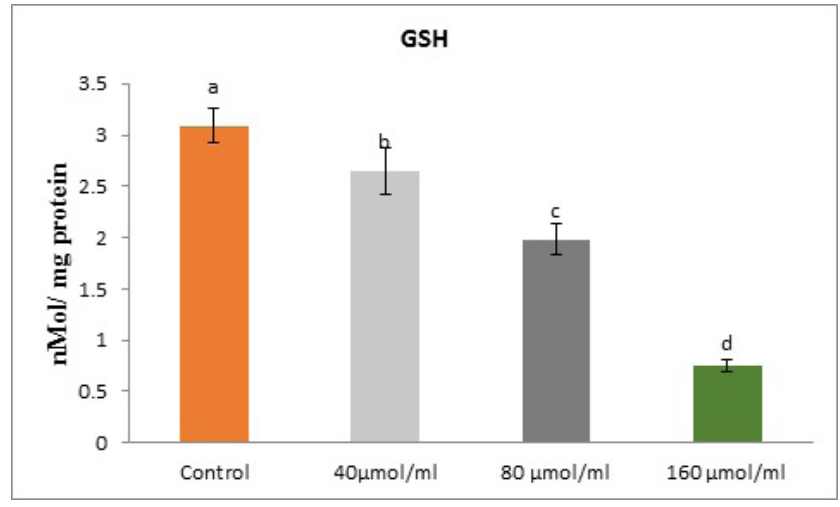

Figure 7. Reduced Glutathione (GSH) levels in alpha-amyrin treated Hep2 cells.

Cancer is the second most common cause of death in western countries and the leading cause in developing countries. Human epidermoid Hep2 cells are used widely for in vitro studies on larynx carcinoma. Most of the larynx carcinoma cancers are established from the 
squamous cells. Epidemiological studies have addressed the scientific validation of plant derived synthetic agents capable of favourably modulating carcinogenic process. Polyphenols have been shown to exert anticancer properties via mechanisms that include antioxidant, antiproliferative and anti-inflammatory activities ${ }^{6}$. Therefore antioxidant rich foods help in inhibition of cancer.

MTT is a technique which is used to assess cytotoxicity or cell viability. Principally MTT enters into the mitochondria and react with mitochondrial dehydrogenase, and is reduced to an unsolvable, colored (dark purple) formazan product. It is then solubilised with an organic solvent and then solubilised Formosan reagent is measured spectrophotometrically ${ }^{7}$. Here, alpha amyrin react with human laryngeal cancer (Hep2) cells, induce cytotoxicity and cells become metabolically inactive. MTT enters into the inactive cells and couldn't cause any color reduction. The level of cell activity is a measure of the viability of the cells. The quantitative variation of the Alpha amyrin possesses significant activity on Hep2 cell lines. Our results showed alpha-amyrin decreased cell viability with an $\mathrm{IC}_{50}$ value of $69.32 \mu \mathrm{mol} / \mathrm{ml}$. The levels of lipid peroxidation marker such as TBARS were significantly depleted in cancer cells, which were significantly increased on alpha-amyrin treated Hep2 cells. Among three different concentrations of $\alpha$-amyrin (40, 80 and $160 \mu \mathrm{mol} / \mathrm{ml})$, higher dose $(160 \mu \mathrm{mol} / \mathrm{ml})$ exposed excellent activity when compared to other two doses. Thereby alpha amyrin inhibits higher amount of cellular proliferation.

The antioxidant enzymes present in nearly all living organisms, which break down the harmful oxygen molecules, thereby prevent the cells and tissues from damage. This kind of enzymes would be utilized much more levels to manage the oxygen demand in cancerous condition. This leads to decreased levels of antioxidants in cancer cells. The activities of enzymatic antioxidants (SOD, CAT and GPx) and the non-enzymatic antioxidants (GSH) were significantly increased in Hep2 cancer cells, whereas administration of alpha-amyrin (40, 80 and 160 $\mu \mathrm{mol} / \mathrm{ml}$ ) significantly decreased the above parameters in Hep2 cancer cells. The higher difference was observed in the $160 \mu \mathrm{mol} / \mathrm{ml}$ of alpha-amyrin when compared to other two doses. Recent studies in our laboratory, we have previously demonstrated that the depleted TBARS levels and increased antioxidant status observed in Hep2 cancer cells, whereas, the treated cells were showed reversed range. This is because of the higher uptake of this enzymes by cells to salvage the lipid peroxides ${ }^{8,9}$, as well as pro oxidant mechanism.

The present studies also confirm the same at the treatment of alpha-amyrin on Hep2 cells. Thus it could be justified that alpha amyrin induces the cytotoxicity by means of pro-oxidant action on Hep2 cancer cell lines and there by inhibit the proliferation as well as promotion of laryngeal carcinoma.

\section{Conclusion}

In our study the effect of alpha amyrin on human laryngeal cancer cell line were assayed to explore its cytotoxicity, oxidant and anti-oxidant status modifications. The results showed that alpha amyrin possess potent anticancer effect through the induction of cytotoxicity and alternative in oxidative stress pathways. Based on this finding alpha amyrin may be a potential natural product against various types of malignancy.

\section{References}

1. Niehaus WG Jr, Samuelsson B. Formation of malondialdehyde from phospholipids arachidonate during microsomal lipid peroxidation. Eur J Biochem. 1968; 61:26-130.

2. Kakkar P, Das B, Viswanathan PN. A modified spectrophotometric assay of Superoxide Dismutase (SOD). Indian J Biochem Biophys. 1984; 21:130-2.

3. Sinha AK. Colorimetric assay of catalase. Anal Biochem. 1972; 47:389-94.

4. Rotruck JT, Pope AL, Ganther HE, Swanson AB, Hafeman DG, Hoekstra WG. Selenium; biochemical roles as a component of glutathione. Science. 1973; 179:588-90.

5. Ellman GL. Tissue sulfhydryl groups. Arch Biochem Biophys. 1959; 82(1):70-7.

6. Yang CS, Landau JM, Huang MT, Newmark HL. Inhibition of carcinogenesis by dietary polyphenolic compounds. Annu Rev Nutr. 2001; 21:381-406.

7. Carrasco C, Rodriguez AB, Pariente JA. Effects of melatonin on the oxidative damage and pancreatic antioxidant defenses in cerulein-induced acute pancreatitis in rats. Hepatobiliary Pancreat Dis Int. 2014; 13:442-6.

8. Rosarin FS, Arulmozhi V, Nagarajan S, Mirunalini S. Antiproliferative effect of silver nanoparticles synthesized using amla on Hep 2 cell line. Asian Pacific Journal of Tropical Medicine. 2012;1-10.

9. Mirunalini S, Deepalakshmi K, Manimozhi J. Antiproliferative effect of coumarin by modulating oxidant/antioxidant status and inducing apoptosis in Hep 2 cells. Biomedicine and Aging Pathology. 2014; 4:131-5. 